\title{
Comparative Study on the Competency of Classifying between Chinese and U.S. First Grade Students
}

\author{
Jin Chen \\ Zhejiang International Studies University, China \\ Jing Cheng \\ East China Normal University, China \\ Shuhua An \\ California State University Long Beach, USA \\ Weidong Wu \\ Zhejiang International Studies University, China \\ Cui Jiang \\ Hangzhou Wenyi Street Primary School, China
}

The study compared the competency in classifying between 255 Chinese and U.S. first grade students in elementary schools. The results showed that some students classified the objects according to their appearance, such as color or shape, while other students differentiated one partition from another depending on the quantity of the objects. Most of the Chinese students preferred to classify the objects according to color or shape while more U.S. students tended to divide the objects evenly. The findings are meaningful for mathematics teaching and learning in elementary schools.

Keywords: Classification, criterion, elementary mathematics, Cross-national comparison

In the last several decades, a number of studies have focused on students' classifications (Vinacke, 1952). Some researchers have limited it to an empirical determination of the extent to which children are able to classify or cross-classify at different ages (Annett, 1959; Hazlitt, 1930). Researchers have noted concerns about establishing the precise relation between the classifications by children and the kinds of inferences they make on the basis of these classifications (Inhelder \& Piaget, 1969). However, few studies focus on the comparison between the competencies in classifying for the lower grades. This study was designed to compare the competency in classifying between Chinese and U.S. first grade students in elementary school. This study also examined the similarities and differences between Chinese and U.S. students' solution of the problems on dividing the given objects. 


\section{Theoretical Framework}

\section{Research on Classification}

Piaget (1965) pointed out that a correct understanding of classificatory relations is essential to an adequate conception of number. The existing body of research on classifying agreed that the competency of classifying is important for mathematics learning. McLeod (2010) considered the competency of classification as the ability to identify the properties of categories, relates categories to one another and uses categorical information to solve problems. In particular, one classification skill is the ability to group objects. Wu and An (2015) defined classification as being able to "separate objects into different categories with common attributes" (p.117). Sheffield and Cruikshank (2000) indicated that children can make comparisons among objects using a systematic classifying scheme.

The mastery of classifying skills not only teaches children about attributes and relationships, but also promotes thinking logically and applying rules (National Council of Teachers of Mathematics [NCTM], 2000). In fact, this skill is a basis for concept development. In addition, "classifying and ordering are natural and interesting to children" (NCTM, 2000, p. 37). Therefore, supporting children to develop classification skills is a vital responsibility of a teacher (Tucker, Singleton, \& Weaver, 2002). Researchers have emphasized on the criteria of classification and implied that classification only becomes logical when paired with an explicit recognition of the criteria (Inhelder \& Piaget, 1969).

\section{Cross-National Studies}

Many previous cross-national studies "have provided a large body of knowledge about students' mathematical achievement in different cultures and about which cultural and educational factors might influence their learning of mathematics" (Cai, 1995, p. 5). Several studies focused on examining crossnational similarities and differences in cognitive aspects of mathematical problem solving (Becker, 1992; Cai, 1995; Mayer, Tajika, \& Stanley, 1991). Most of the researchers used quantitative methods to compare the mathematical learning between Chinese and U.S. students. Some researchers focused on specific mathematical problems and applied qualitative research methods to analyze the similarities and differences inf cognition between Chinese and U.S. students (Cai, 1995; Cai \& Wang, 2006).

This study used both quantitative and qualitative methods to compare the competency of classifying between Chinese and U.S. first grade students in elementary schools. This study seeks to answer the following related research questions: 1) How do the first grade students divide the given objects in each country? 2) What are the main similarities and differences regarding the competency in classifying between Chinese and U.S. first grade students in elementary schools? 


\section{Method}

\section{Participants}

This research was conducted with 255 first grade students from a Chinese elementary school in Hangzhou, China and an American elementary school in Southern California, United States. All students were assessed via a problem-solving test (Browning, \& Lehman, 1988) on dividing 6 candies. As shown in Table 1, there were 152 Chinese students ( 83 males and 69 females), and 103 students from the U.S., (50 were males and 53 females).

Table 1

Students' Demographic Information

\begin{tabular}{lccl}
\hline City & \# of Students & Male & Female \\
\hline Hangzhou (CN) & 152 & 83 & 69 \\
Southern California (US) & 103 & 50 & 53 \\
\hline
\end{tabular}

\section{Data Collection and Instrument}

Data was collected using a problem-solving test created by the authors. This test included only one question, but the same question was asked in three different ways. The first time (T1): please use different colored pencils to divide these candies (see Figure 1). The second time (T2): do you have another way to divide them (see Figure 2)? The third time (T3): if you still have other ways, please divide them (see Figure 3).

please use different colored pencils to divide these candies

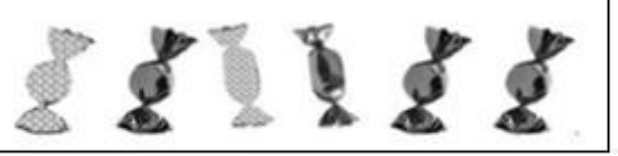

Figure 1. The first time dividing.

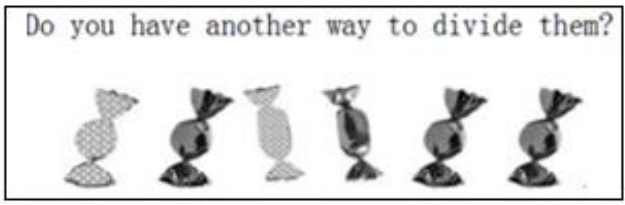

Figure 2. The second time dividing.

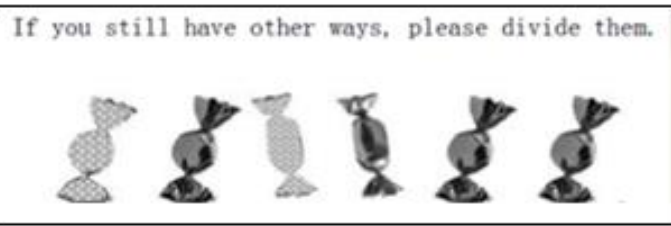

Figure 3. The third time dividing the candies.

The same question was asked three times in the questionnaire for two reasons. First, without providing any preconditions, there are many possible ways to interpret "dividing objects", such as dividing by appearance and by quantity. Therefore, repeated questions allow students to exhaust all the 
possibilities they can think of and this will also provide valid and comprehensive data. Secondly, among all the possibilities, the answer to T1 is regarded as a preconceived method. This reflects students' priority in classification.

\section{Data Analysis}

Both quantitative and qualitative methods were employed to examine the research questions. The students' responses on dividing the objects were categorized into seven types. Table 2 shows the categories.

Among them, Type 2 and Type 3 reflected students' inability in dividing objects with explicit criterion; Type 4 and Type 5 were based on the criterion of appearance; and Type 6 and Type 7 were based on the criterion of quantity. In addition, $\mathrm{T} 2$ analysis has $\mathrm{S} 1$, which means the students' responses were the same as T1. Similarly, T3 analysis has S1 and S2, with S2 meaning that the students' responses were the same as $\mathrm{T} 2$.

\section{Results}

\section{The First Time Students Divided Objects}

Chinese and U.S. students' overall competency in classifying. Table 3 shows that most of the students (39.6\%) divided objects according to different colors, $24.7 \%$ of them divided evenly, and $12.5 \%$ of them divided with mixed criteria according to the appearance of the objects. However, it is impossible for them to classify smoothly when following the criterion of color and the criterion of shape simultaneously.

The comparison between Chinese and U.S. students. Table 4 reveals that Chinese and U.S. students' criteria of classification were different when they divided objects for the first time. Table 4 shows that $44.1 \%$ of Chinese students preferred the criterion of color, only $33.0 \%$ of U.S. students made the same choice. $35.9 \%$ of U.S. students divided objects evenly, as compared to only $17.1 \%$ of Chinese students. It is worth noting that $11.8 \%$ of Chinese students preferred the criterion of shape, but none of the U.S. student followed this criterion. While $14.6 \%$ of U.S. students preferred to divide objects according to decomposing a number as a sum, none of the Chinese student followed this criterion. 
Table 2

\section{Categories of Seven Types of Dividing the Objects}

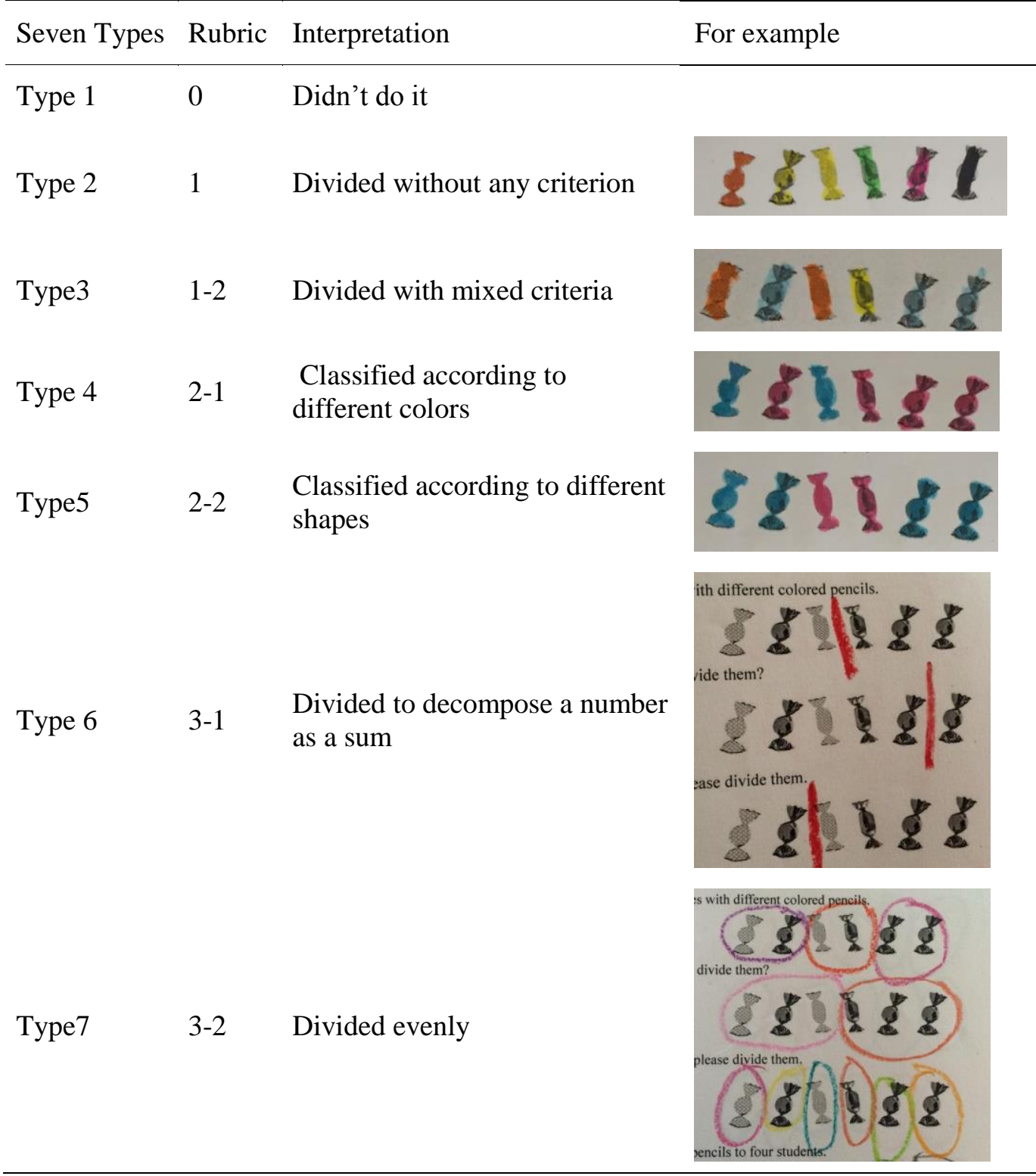


Table 3

Students' Responses to T1

\begin{tabular}{lllll}
\hline & Frequency & Percent & $\begin{array}{l}\text { Valid } \\
\%\end{array}$ & $\begin{array}{l}\text { Cumulative } \\
\%\end{array}$ \\
\hline 0 Didn't do it & 1 & .4 & .4 & .4 \\
1 Divided without any criterion & 25 & 9.8 & 9.8 & 10.2 \\
$\begin{array}{l}\text { 1-2 Divided with mixed criteria } \\
\text { 2-1 Classified according to unusual }\end{array}$ & 32 & 12.5 & 12.5 & 22.7 \\
$\begin{array}{l}\text { colors } \\
\text { 2-2 Classified according to different }\end{array}$ & 101 & 39.6 & 39.6 & 62.4 \\
shapes & 18 & 7.1 & 7.1 & 69.4 \\
3-1 Divided to decompose a number as & 15 & 5.9 & 5.9 & 75.3 \\
$\begin{array}{l}\text { a sum } \\
\text { 3-2 Divided evenly }\end{array}$ & 63 & 24.7 & 24.7 & 100.0 \\
Total & 255 & 100.0 & 100.0 & \\
\hline
\end{tabular}

Table 4

Chinese and U.S. Students' Responses to T1

\begin{tabular}{|c|c|c|c|c|c|}
\hline & & Frequency & Percent & Valid \% & $\begin{array}{l}\text { Cumulative } \\
\%\end{array}$ \\
\hline \multirow[t]{6}{*}{ China } & 0 Didn't do it & 0 & 0 & 0 & 0 \\
\hline & 1 Divided without any criterion & 13 & 8.6 & 8.6 & 8.6 \\
\hline & 1-2 Divided with mixed criteria & 28 & 18.4 & 18.4 & 27.0 \\
\hline & $\begin{array}{l}\text { 2-1 Classified according to different } \\
\text { colors }\end{array}$ & 67 & 44.1 & 44.1 & 71.1 \\
\hline & $\begin{array}{l}\text { 2-2 Classified according to different } \\
\text { shapes }\end{array}$ & 18 & 11.8 & 11.8 & 82.9 \\
\hline & $\begin{array}{l}\text { 3-1 Divided to decompose a number } \\
\text { as a sum }\end{array}$ & 0 & 0 & 0 & 82.9 \\
\hline \multirow[t]{10}{*}{ U.S. } & 3-2 Divided evenly & 26 & 17.1 & 17.1 & 100.0 \\
\hline & Total & 152 & 100.0 & 100.0 & \\
\hline & 0 Didn't do it & 1 & 1.0 & 1.0 & 1.0 \\
\hline & 1 Divided without any criterion & 12 & 11.7 & 11.7 & 12.6 \\
\hline & 1-2 Divided with mixed criteria & 4 & 3.9 & 3.9 & 16.5 \\
\hline & $\begin{array}{l}\text { 2-1 Classified according to different } \\
\text { colors }\end{array}$ & 34 & 33.0 & 33.0 & 49.5 \\
\hline & $\begin{array}{l}\text { 2-2 Classified according to different } \\
\text { shapes }\end{array}$ & 0 & 0 & 0 & 49.5 \\
\hline & $\begin{array}{l}\text { 3-1 Divided to decompose a number } \\
\text { as a sum }\end{array}$ & 15 & 14.6 & 14.6 & 64.1 \\
\hline & 3-2 Divided evenly & 37 & 35.9 & 35.9 & 100.0 \\
\hline & Total & 103 & 100.0 & 100.0 & \\
\hline
\end{tabular}

\section{The Second Time Students Divided Objects}

Chinese and U.S. students' overall competency in classifying. Table 5 shows that for $\mathrm{T} 2,36.1 \%$ of the students did the same as in $\mathrm{T} 1$ when they divided objects without trying a new criteria of classifying. $15.3 \%$ of the students classified according to shape and $5.5 \%$ of the students did nothing. 
The comparison between Chinese and U.S. students. When dividing objects in T2, Table 6 reveals that the proportion of U.S. students who divided without any criterion increased to $18.4 \%$, while the proportion of Chinese students who did that was only $3.9 \%$. The proportion of Chinese students who divided objects according to "shape" increased to $19.7 \%$, while the proportion of U.S. students who did the same was $8.7 \%$. Exactly $38.8 \%$ of Chinese students divided objects the same way as they had done for the first time, with the comparable percentage for U.S. students being $32 \%$.

\section{The Third Time Students Divided Objects}

Chinese and U.S. students' overall competency in classifying. When dividing objects in T3, almost half (43.9\%) of all the students classified the objects in the same way as they had done for the previous two times, $10.6 \%$ left this question blank, and $14.1 \%$ divided without any criterion (see Table7).

The comparison between Chinese and U.S. students. Table8 shows that $51.3 \%$ of Chinese students did the same way as they had done for the previous two times when they were dividing objects for the third time, while the comparable percentage for U.S. students is $33 \%$. And when it comes to the combined percentage of students who left it blank and who divided without any criterion, $17.7 \%$ for Chinese students versus $35 \%$ for U.S. students is also quite notable.

Table 5

Students' Responses to T2

\begin{tabular}{lllll}
\hline & $\begin{array}{l}\text { Frequen } \\
\text { cy }\end{array}$ & $\begin{array}{l}\text { Percen } \\
\text { t }\end{array}$ & $\begin{array}{l}\text { Valid } \\
\%\end{array}$ & $\begin{array}{l}\text { Cumulati } \\
\text { ve } \%\end{array}$ \\
\hline Valid $\begin{array}{l}\text { 0 Didn't do it } \\
\begin{array}{l}\text { 1 Divided without any } \\
\text { criterion }\end{array}\end{array}$ & 14 & 5.5 & 5.5 & 5.5 \\
$\begin{array}{l}\text { 1-2 Divided with mixed } \\
\text { criteria }\end{array}$ & 12 & 4.7 & 4.7 & 20.0 \\
$\begin{array}{l}\text { 2-1 Classified according to } \\
\text { different colors }\end{array}$ & 26 & 10.2 & 10.2 & 30.2 \\
$\begin{array}{l}\text { 2-2 Classified according to } \\
\text { different shapes }\end{array}$ & 39 & 15.3 & 15.3 & 45.5 \\
$\begin{array}{l}\text { 3-1 Divided to decompose a } \\
\text { number as a sum }\end{array}$ & 12 & 4.7 & 4.7 & 50.2 \\
$\begin{array}{l}\text { 3-2 Divided evenly } \\
\begin{array}{l}\text { S1 Students' responses were } \\
\text { the same as T1 }\end{array}\end{array}$ & 35 & 13.7 & 13.7 & 63.9 \\
\begin{tabular}{l} 
Total \\
\hline
\end{tabular} & 255 & 100.0 & 100.0 & \\
\hline
\end{tabular}


Table 6

\section{Chinese and U.S. Students' Responses to T2}

\begin{tabular}{|c|c|c|c|c|c|}
\hline & & Frequency & Percent & Valid \% & $\begin{array}{l}\text { Cumulative } \\
\%\end{array}$ \\
\hline \multirow[t]{6}{*}{ China } & 0 Didn't do it & 3 & 2.0 & 2.0 & 2.0 \\
\hline & 1 Divided without any criterion & 6 & 3.9 & 3.9 & 5.9 \\
\hline & 1-2 Divided with mixed criteria & 11 & 7.2 & 7.2 & 13.2 \\
\hline & $\begin{array}{l}2-1 \text { Classified according to different } \\
\text { colors }\end{array}$ & 25 & 16.4 & 16.4 & 29.6 \\
\hline & $\begin{array}{l}\text { 2-2 Classified according to different } \\
\text { shapes }\end{array}$ & 30 & 19.7 & 19.7 & 49.3 \\
\hline & $\begin{array}{l}\text { 3-1 Divided to decompose a number as a } \\
\text { sum }\end{array}$ & 0 & 0 & 0 & 49.3 \\
\hline \multirow[t]{12}{*}{ U.S. } & 3-2 Divided evenly & 18 & 11.8 & 11.8 & 61.2 \\
\hline & $\begin{array}{l}\text { S1 Students' responses were the same as } \\
\mathrm{T} 1\end{array}$ & 59 & 38.8 & 38.8 & 100.0 \\
\hline & Total & 152 & 100.0 & 100.0 & \\
\hline & 0 Didn't do it & 11 & 10.7 & 10.7 & 10.7 \\
\hline & 1 Divided without any criterion & 19 & 18.4 & 18.4 & 29.1 \\
\hline & 1-2 Divided with mixed criteria & 1 & 1.0 & 1.0 & 30.1 \\
\hline & $\begin{array}{l}2-1 \text { Classified according to different } \\
\text { colors }\end{array}$ & 1 & 1.0 & 1.0 & 31.1 \\
\hline & $\begin{array}{l}\text { 2-2 Classified according to different } \\
\text { shapes }\end{array}$ & 9 & 8.7 & 8.7 & 39.8 \\
\hline & $\begin{array}{l}\text { 3-1 Divided to decompose a number as a } \\
\text { sum }\end{array}$ & 12 & 11.7 & 11.7 & 51.5 \\
\hline & 3-2 Divided evenly & 17 & 16.5 & 16.5 & 68.0 \\
\hline & $\begin{array}{l}\text { S1 Students' responses were the same as } \\
\text { T1 }\end{array}$ & 33 & 32.0 & 32.0 & 100.0 \\
\hline & Total & 103 & 100.0 & 100.0 & \\
\hline
\end{tabular}

Table 7

Students' Responses to T3

\begin{tabular}{|c|c|c|c|c|c|}
\hline & & Frequency & Percent & Valid $\%$ & $\begin{array}{l}\text { Cumulative } \\
\%\end{array}$ \\
\hline \multirow[t]{10}{*}{ Valid } & 0 Didn't do it & 27 & 10.6 & 10.6 & 10.6 \\
\hline & 1 Divided without any criterion & 36 & 14.1 & 14.1 & 24.7 \\
\hline & 1-2 Divided with mixed criteria & 8 & 3.1 & 3.1 & 27.8 \\
\hline & $\begin{array}{l}\text { 2-1 Classified according to } \\
\text { different colors }\end{array}$ & 11 & 4.3 & 4.3 & 32.2 \\
\hline & $\begin{array}{l}\text { 2-2 Classified according to } \\
\text { different shapes }\end{array}$ & 20 & 7.8 & 7.8 & 40.0 \\
\hline & $\begin{array}{l}\text { 3-1 Divided to decompose a } \\
\text { number as a sum }\end{array}$ & 9 & 3.5 & 3.5 & 43.5 \\
\hline & 3-2 Divided evenly & 32 & 12.5 & 12.5 & 56.1 \\
\hline & $\begin{array}{l}\text { S1 Students' responses were the } \\
\text { same as } \mathrm{T} 1\end{array}$ & 86 & 33.7 & 33.7 & 89.8 \\
\hline & $\begin{array}{l}\text { S2 Students' responses were the } \\
\text { same as T2 }\end{array}$ & 26 & 10.2 & 10.2 & 100.0 \\
\hline & Total & 255 & 100.0 & 100.0 & \\
\hline
\end{tabular}


Table 8

Chinese and U.S. Students' Responses to T3

\begin{tabular}{|c|c|c|c|c|c|}
\hline & & Frequency & Percent & Valid \% & Cumulative \% \\
\hline \multirow{7}{*}{ China } & 0 Didn't do it & 9 & 5.9 & 5.9 & 5.9 \\
\hline & 1 Divided without any criterion & 18 & 11.8 & 11.8 & 17.8 \\
\hline & 1-2 Divided with mixed criteria & 7 & 4.6 & 4.6 & 22.4 \\
\hline & $\begin{array}{l}\text { 2-1 Classified according to } \\
\text { different colors }\end{array}$ & 10 & 6.6 & 6.6 & 28.9 \\
\hline & $\begin{array}{l}\text { 2-2 Classified according to } \\
\text { different shapes }\end{array}$ & 14 & 9.2 & 9.2 & 38.2 \\
\hline & $\begin{array}{l}\text { 3-1 Divided to decompose a } \\
\text { number as a sum }\end{array}$ & 0 & 0 & 0 & 38.2 \\
\hline & 3-2 Divided evenly & 16 & 10.5 & 10.5 & 48.7 \\
\hline \multirow[t]{13}{*}{ U.S. } & $\begin{array}{l}\text { S1 Students' responses were the } \\
\text { same as T1 }\end{array}$ & 56 & 36.8 & 36.8 & 85.5 \\
\hline & $\begin{array}{l}\text { S2 Students' responses were the } \\
\text { same as T2 }\end{array}$ & 22 & 14.5 & 14.5 & 100.0 \\
\hline & Total & 152 & 100.0 & 100.0 & \\
\hline & 0 Didn't do it & 18 & 17.5 & 17.5 & 17.5 \\
\hline & 1 Divided without any criterion & 18 & 17.5 & 17.5 & 35.0 \\
\hline & 1-2 Divided with mixed criteria & 1 & 1.0 & 1.0 & 36.0 \\
\hline & $\begin{array}{l}\text { 2-1 Classified according to } \\
\text { different colors }\end{array}$ & 1 & 1.0 & 1.0 & 37.0 \\
\hline & $\begin{array}{l}\text { 2-2 Classified according to } \\
\text { different shapes }\end{array}$ & 6 & 5.8 & 5.8 & 42.8 \\
\hline & $\begin{array}{l}\text { 3-1 Divided according to } \\
\text { decompose a number as a sum }\end{array}$ & 9 & 8.7 & 8.7 & 51.5 \\
\hline & 3-2 Divided evenly & 16 & 15.5 & 15.5 & 67.0 \\
\hline & $\begin{array}{l}\text { S1 Students' responses were the } \\
\text { same as T1 }\end{array}$ & 30 & 29.1 & 29.1 & 96.1 \\
\hline & $\begin{array}{l}\text { S2 Students' responses were the } \\
\text { same as T2 }\end{array}$ & 4 & 3.9 & 3.9 & 100.0 \\
\hline & Total & 103 & 100.0 & 100.0 & \\
\hline
\end{tabular}

\section{Discussion}

\section{The Similarities in Classification in Dividing Objects}

The findings from this study show that both Chinese and U.S. students employed criteria of classification related to appearance and quantity of the objects. Criteria related to the appearance were mainly the criterion of "color" and the criterion of "shape". Criteria of quantity were mainly the criterion of "decomposing a number as a sum" and the criterion of "dividing evenly". These findings were supported by Wu and An (2015) in that classification is based on common attributes when separating objects into different categories. In this study, the common attributes include "color" and "shape."

An evident finding from the analysis in this study is that the proportion of Chinese and U.S. students who performed the tasks the same way as they had done before increased when required to divide the same group of objects for the second and third time. The proportion of students who chose to leave it 
blank or divided without a criterion increased too. These results are in agreement with Memon and Vartoukian's (1996) findings, which showed that children increased the total correct information without decreasing the accuracy of responses in repetition of open questions and these questions appear to have no harmful effects.

\section{The Differences in Classification in Dividing the Objects}

It is interesting to note that the preferred criteria were different between Chinese and U.S. students when dividing objects for the first time. The criterion of "color" was the preferred criterion of classification among Chinese students, while "dividing evenly" was the first choice of many U.S. students. This difference may be due to culture and language differences: In Chinese "divide" can mean "distribute", while in U.S. "divide" can mean "fair sharing," which is one common idea often taught by teachers when teaching division. "Fair sharing" tells children "the meaning of division: divide objects evenly and fairly in a given set” (Wu, \&An, 2015, p.166).

In this study, Chinese and U.S. students had their own unique criterion when they divided objects. In each of the three times, some U.S. students divided according to the criterion of "decomposing a number as a sum", but none of the Chinese students did that. For the criterion of "shape", several Chinese students classified objects according to "shape" in all three times. However, none of the U.S. students followed this criterion the first time and only a few students use this in the latter two times.

In these three times, the percentages of Chinese and U.S. students who repeated the same result, who chose to leave it blank and who divided without any criterion were evidently different. The percentage of Chinese students who repeated the same result was much higher than U.S. students. In contrast, the percentages of U.S. students who chose to leave the question blank and who divided without any criterion were much higher than Chinese students.

The above findings are consistent with comparative studies in students' mathematics learning between China and U.S. (Cai, 1995; Li, Chi, DeBey, \& Baroody, 2015). The comparative study by Cai (1995) found that Chinese students performed significantly better than U.S. students on both computation and simple problem solving. Li, Chi, DeBey, and Baroody's study (2015) identified various differences in early childhood mathematics learning. One of the differences is a curriculum difference: early childhood mathematics content in the U.S. appears to be broader and less differentiated by age group than in China. The U.S. now implements the Common Core mathematics standards in the early years to promote teaching mathematics for deep understanding.

In conclusion, classification is a fundamental skill in early mathematics. Not only does it help develop children's early mathematics concepts, but also builds on division concepts and skills for their later learning. The findings on classification in this study provide meaningful insights for mathematics 
teaching and learning at the elementary school level. The findings also contribute to a better understanding of research on how children's learning and understanding of early division are different between China and U.S. This study suggests including more samples and using different objects with various attributes in future studies.

\section{Author Note:}

The first author Jin Chen was supported by MOE (Ministry of Education in China) Funding Project of Liberal Arts and Social Sciences, Project No. 14YJC880004. The corresponding author Jing Cheng was supported by Science and Technology Commission of Shanghai Municipality (STCSM), Grant No. 13dz2260400.

\section{References}

Annett, M. (1959). The classification of four common class concepts by children and adults. British Journal of Psychology, 20.

Becker, J. P. (Ed.). (1992). Report of U.S.-Japan cross-national research on students' problem solving behaviors. Carbondale, IL: Southern Illinois University.

Cai, J. (1995). Cognitive analysis of Chinese and U.S. students' mathematical performance on tasks involving computation, simple problem solving, and complex problem solving. Journal for Research in Mathematics Education, 7, 1-151.

Cai, J., \& Wang, T. (2006). Chinese and U.S. teachers' conceptions and constructions of representations: A case of teaching ratio concept. International Journal of Science and Mathematics Education, 4(1), 145186.

Hazlitt, V. (1930). Children's thinking. British Journal of Psychology, 20, 354-61.

Inhelder, B., \& Piaget, J. (1969). The early growth of logic in the child. New York, NY: The Norton Library.

Mayer, R. E., Tajika, H., \& Stanley, C. (1991). Mathematical problem solving in Japan and the United States: A controlled comparison. Journal of Education al Psychology, 83(1), 69-72.

McLeod, S. A. (2010). Concrete operational stage. Retrieved from www.simplypsychology.org/concrete-operational.html

Memo, A., \& Arthurian, R. (1996). The effects of repeated questioning on young children's eyewitness testimony. British Journal of Psychology, 87, 403-415

NCTM. (2000). Principles and standards for school mathematics. Reston, VA: Author. 
Piaget, J. (1965). The child's conception of number. New York, NY: The Norton Library.

Sheffield, L. J., \& Cruikshank, D. E. (2000). Teaching and learning elementary and middle school mathematics. New York, NY: John Wiley $\&$ Sons.

Tucker, B., Singleton, A. H., \& Weaver, T. L. (2002). Teaching mathematics to all children. Upper Saddle Creek, NJ: Merrill Prentice Hall.

Vinacke, W.E. (1952). The psychology of thinking. New York, NY: McGrawHill.

Wu, Z., \& An, S. (2015). Teaching elementary and middle school mathematics. Irvine, CA: Education for All.

Li, X., Chi, L., DeBey, M., \& Baroody, A. J. (2015). A study of early childhood mathematics teaching in the United States and China. Early Education And Development, 26 (3), 450-478.

\section{Authors:}

Jin Chen

Zhejiang International Studies University, China

Email: chenjin@zisu.edu.cn

Jing Cheng

East China Normal University, China

Email: jcheng@math.ecnu.edu.cn

Shuhua An

California State University, Long Beach, USA

Email:Shuhua.An@csulb.edu

Weidong $W u$

Zhejiang International Studies University, China

Email:wwd@zisu.edu.cn

Cui Jiang

Hangzhou Wenyi Street Primary School, China

Email:1051032631@qq.com 